\title{
Analisis Faktor-faktor yang Berhubungan dengan Kejadian Lesi Pra Kanker Serviks pada Wanita Pasangan Usia Subur di Wilayah Kerja Puskesmas Muara Bungo 1
}

\author{
Citra Ayu Fitrisia' ${ }^{1}$ Daan Khambri², Bobby Indra Utama ${ }^{3}$, Syamel Muhammad ${ }^{3}$
}

\begin{abstract}
Abstrak
Lesi pra kanker serviks adalah awal perubahan menuju kanker serviks. Program pengendalian kanker serviks melalui pemeriksaan Visual Inspection with Acetic Acid (VIA) di tingkat Puskesmas dapat menurunkan insiden kanker serviks hingga $83,6 \%$. Kanker serviks ini berkaitan dengan banyak faktor risiko.Tujuan: Menganalisis hubungan antara faktor risiko dengan kejadian lesi pra kanker serviks. Metode: Cross sectional yang dilakukan di wilayah kerja Puskesmas Muara Bungo 1 dari bulan Februari sampai Mei 2019 terhadap 362 responden. Pengambilan sampel menggunakan metode multistage random sampling. Pengambilan data menggunakan kuisioner dan observasi. Data dianalisis menggunakan uji Chi-square. Hasil: Terdapat hubungan signifikan $(p<0,05)$ antara kejadian lesi prakanker serviks dengan usia $>35$ tahun, usia pertama kali berhubungan seksual $<20$ tahun, jumlah paritas $\geq 4$ kali, menggunakan pembersih vagina dan lama penggunaan kontrasepsi hormonal $\geq 5$ tahun. Jumlah pasangan seksual, paparan asap rokok dan riwayat keluarga kanker serviks, tidak memiliki hubungan yang signifikan dengan kejadian lesi pra kanker serviks $(p \geq 0,05)$. Faktor risiko yang paling dominan adalah usia pertama kali berhubungan seksual $<20$ tahun ( $p=0,008$; OR: 6,092). Simpulan: Faktor risiko usia, usia pertama kali berhubungan seksual, jumlah paritas, menggunakan pembersih vagina dan lama menggunakan kontrasepsi hormonal berhubungan dengan kejadian lesi prakanker serviks.
\end{abstract}

Kata kunci: lesi pra kanker serviks, VIA, faktor-faktor risiko

\begin{abstract}
The program for controlling cervical cancer through Visual Inspection with Acetic Acid (VIA) at the Public Health level can reduce the incidence of cervical cancer by $83.6 \%$. This cervical cancer is associated with many risk factors. Objectives: To analyzed the relationship between risk factors and the incidence of precancerous lesion of cervical. Methods: This was a cross sectional design with multistage random sampling method. This study was conducted at Muara Bungo 1's Health Center from February until May in 2019 on 362 respondents. Sampling uses the Multistage Random Sampling Method. The data collected by questionnaires and observations. Data were analyzed by Chi-square test. Results: There were significant relationship $(p<0.05)$ between the incidence of pre-cervical cancer lesions with risk factors of age more than 35 years old, age of first sexual intercourse less than 20 years old, the number of parity at least for four times, using vaginal cleansers and duration of use of hormonal contraception at least for five years, exposure to cigarette smoked and a family history of cervical cancer, did not have a significant relationship with the incidence of pre-cancerous lesions of cervical cancer ( $p>0.05)$. The most dominant risk factor was the age of first sexual intercourse less than twenty years old. $(p=0.008$; OR: 6,092). Conclusion: The risk factor of age, age of first sexual intercourse, the number of parity, using vaginal cleansers and duration of use of hormonal contraception relations with the precancerous lesion of cervical.
\end{abstract}

Keywords: precancerous lesion of cervical, VIA, risk factors 
Affiliasi penulis: 1. Unit Pelayanan Terpadu Puskesmas Muara Bungo 1, 2. Bagian Bedah Fakultas Kedokteran Universitas Andalas Padang (FK Unand), 3. Bagian Obstetri-Ginekologi FK Unand Korespondensi : Dr.dr. Daan Khambri,Sp.B(K)-Onk.M.Kes, Email: daan_khambri@yahoo.com, Telp: 081226586000

\section{PENDAHULUAN}

Kanker serviks atau kanker leher rahim adalah salah satu penyakit keganasan atau neoplasma yang terjadi di daerah leher rahim atau mulut rahim yang merupakan bagian terendah dari rahim yang menonjol kepuncak liang sanggama (vagina). ${ }^{1}$ Penyebab penyakit ini adalah virus HPV (Human Papiloma Virus) tipe onkogenik dan banyak diderita oleh wanita yang telah menikah atau aktif dalam melakukan aktifitas seksual. $^{2}$

Penyakit ini menempati urutan keempat dari 5 penyakit kanker terbanyak pada wanita di dunia (kanker payudara, kolonrektum, paru-paru, kanker serviks dan tiroid). Di negara-negara berkembang, umumnya kanker serviks menempati urutan pertama sebagai penyebab kematian pada wanita di usia subur. Menurut Organisasi Penanggulangan Kanker Dunia dan Badan Kesehatan Dunia, di perkirakan terjadi peningkatan kejadian kanker di dunia 300 persen pada tahun $2030 .^{3}$ Kanker seviks adalah salah satu penyumbang angka kematian pada perempuan yang cukup tinggi di mana kondisi ini mayoritas terjadi di negara-negara berkembang. ${ }^{4}$ Berdasarkan data Global Burden Cancer atau Interntional Agency for Research on Cancer (IARC) diketahui bahwa penyebab kematian tertinggi setelah kanker payudara adalah kanker serviks yang merupakan kanker ginekologi penyumbang penyebab kematian tertinggi pada wanita. ${ }^{4}$ Fakta lain di ungkap bahwa penderita kanker serviks di dunia semakin meningkat dari tahun ketahun dengan angka mencapai lebih dari 460.000 kasus dan 230.000 perempuan meninggal dunia karena penyakit tersebut. ${ }^{5}$

Kanker serviks di Indonesia merupakan kanker yang paling umum terjadi dengan tingkat kejadian 23,4 per 100.000 penduduk dengan kematian 13,9 per 100.000 penduduk. $^{6}$ Kondisi ini membuat kanker serviks disebut sebagai penyakit pembunuh wanita nomor satu di Indonesia. Kematian ini dihubungkan dengan sebagaian besar stadium kanker serviks
(80\%) adalah stadium invasif, lanjut dan bahkan stadium terminal pada saat diagnosis di tegakkan. ${ }^{7}$

Masa proliferasi sel atau jaringan normal hingga menjadi abnormal atau kanker, tidak secepat yang dibayangkan. Artinya sebelum terjadi kanker, akan didahului dengan keadaan yang disebut dengan lesi pra kanker atau Neoplasia Intraepitel Serviks (NIS), perlu waktu sekitar 10-20 tahun sebelum berkembang menjadi kanker. NIS merupakan awal dari perubahan menuju karsinoma serviks. ${ }^{8}$ Pada stadium lanjut, kanker serviks dapat menyebabkan kematian dalam waktu cepat. Kanker serviks tergolong penyakit tidak menular, tidak muncul secara tiba-tiba dan merupakan kumpulan dari multifaktor risiko. ${ }^{9}$ Mengatasi masalah kejadian kanker serviks pemerintah menyatakan bahwa kunci keberhasilan program pengendalian kanker leher rahim adalah penapisan (screening) yang diikuti dengan pengobatan yang adekuat (see and treat) salah satunya dengan metode Visual Inspection with Acetic Acid (VIA) serta pengendalian faktor risiko. ${ }^{7}$ VIA di pilih karena memiliki sensitivitas dan spesifisitas yang tidak jauh berbeda dengan tes PAP dan cukup murah, mudah serta cepat hasil yang di dapat. ${ }^{10}$

Beberapa penelitian telah banyak dilakukan untuk menggali keterkaitan faktor risiko yang berhubngan dengan kejadian lesi pra kanker serviks yang merupakan awal perubahan menuju kanker serviks. Penelitian di Afrika selatan oleh Makuza et al menyimpulkan faktor risiko yang menyebabkan kanker serviks adalah aktivitas seksual pada umur kurang dari 20 tahun $(\mathrm{OR}=3,29)$ dan paritas $(\mathrm{OR}=$ 0,42). ${ }^{10}$ Sedangkan di Eropa oleh disimpulkan bahwa merokok, usia <20 tahun saat hubungan seksual pertama, jumlah partner seksual, riwayat keluarga dan pemakaian kontrasepsi hormonal dalam jangka waktu yang lama. ${ }^{3}$

Strategi yang ditempuh untuk mengevaluasi keberhasilan program deteksi tersebut adalah menilai capaiann target cakupan. Cakupan deteksi dini dengan IVA minimal $85 \%$ selama lima tahun, dapat menurunkan insiden kanker leher rahim secara signifikan hingga $83,6 \% .^{3}$ Saat ini cakupan screening deteksi dini kanker serviks dengan metode VIA di Indonesia sampai 2017 terbilang masih rendah 
(2,97\%). ${ }^{11}$ Target program minimal yang diharapkan tercapai dalam lima tahun terhitung 2015-2019 adalah minimal $50 \% .^{12}$ Tingginya temuan lesi pra kanker serviks bahkan kanker serviks itu sendiri di setiap provinsi, akan berbanding lurus dengan tingginya cakupan deteksi dini yang di lakukan. ${ }^{13}$

Pada kegiatan deteksi dini kanker serviks dalam kurun waktu hingga tahun 2017, Indonesia belum dapat memenuhi target cakupan pemeriksaan VIA pada angka $30 \%$. Artinya cakupan pemeriksaan VIA di Indonesia hanya 2,9\% dimana Kepulauan Bangka Belitung (13,1\%) memiliki cakupan tertinggi yang di ikuti oleh Sumatera Barat $(9,3 \%)$, Kalimantan Selatan (8,7\%) dan Lampung (6,6\%). Sedangkan Provinsi Jambi berada pada peringkat ke 13 sebesar $3,8 \%$ dari 34 provinsi yang ada. Prevalensi kasus kanker serviks di provinsi Jambi yakni 1.729 kasus dan pernah lebih tinggi dari kanker payudara. ${ }^{12}$ Provinsi Jambi, kurun waktu sampai juli 2018 telah terjaring 1.027 orang wanita menikah usia 30-50 yang positif lesi pra kanker serviks (dari 29.776 orang yang diperiksa). Jumlah penjaringan tersebut masih jauh dari target sasaran yang seharusnya yakni : 207.186 orang (target 40\%) sampai 2018. ${ }^{14}$

Kabupaten Bungo yang merupakan salah satu kabupaten yang ada di Provinsi jambi dari 11 Kabupaten yang ada, menyumbang 27 orang wanita yang positif IVA lesi pra kanker serviks. ${ }^{15}$ Sepanjang Januari sampai November 2018 terdapat 6 orang dengan kanker serviks. ${ }^{16}$ Puskesmas Muara bungo 1 merupakan salah satu puskesmas dari 18 puskesmas yang ada di Kabupaten Bungo dengan jumlah sasaran wanita Pasangan Usia Subur (PUS) tertinggi namun masih memiliki cakupan deteksi dini kanker serviks dengan metode IVA yang terbilang rendah yakni 11,9\% (dari 2015-31 juli 2018). ${ }^{15}$

Program deteksi dini pemeriksaan VIA di tingkat Puskesmas secara periodik dan mengendalikan faktor risiko, merupakan salah satu cara efektif untuk mencegah terjadinya lesi pra kanker serviks sebelum menjadi kanker serviks. Belum diketahuinya secara literatur tentang faktor-faktor yang berhubungan dengan kejadian lesi pra kanker pada wanita PUS di Kabupaten Bungo, maka peneliti tertarik untuk melakukan penelitian terkait faktor-faktor tersebut di Puskesmas yakni puskesmas Muara Bungo 1.

\section{METODE}

Penelitian ini menggunakan rancangan penelitian analitik observasional dengan desain cross sectional di wilayah kerja Puskesmas Muara Bungo 1 dengan metode wawancana langsung dengan kuisioner yang dijadikan sebagai acuan dan observasi dengan pemeriksaan VIA. Waktu penelitian dari bulan Februari-Mei 2019. Populasi penelitian ini adalah seluruh wanita PUS yang berdomisili di wilayah kerja Puskesmas Muara Bungo 1 dan belum pernah mendapatkan pemeriksaan deteksi dini lesi prakanker serviks atau pernah menjalankan tes 3 tahun sebelumnya atau lebih dengan metode IVA sebanyak 3.833 orang. Subjek penelitian yang dipilih adalah memenuhi kriteria inklusi dan ekslusi, dengan teknik pengambilan sampel secara Multistage Simple Random Sampling.

Kriteria inklusinya adalah Wanita yang berumur 20-50 tahun dan bersedia menjadi responden dalam penelitian dengan menandatangani lembar persetujuan penelitian (informed Consent). Sedangkan kriterian eksklusinya adalah wanita pasangan usia subur yang dalam keadaan hamil, SSK yang tidak terlihat sehingga pada wanita tersebut tidak bisa dilakukan pemeriksaan VIA dan wanita yang dicurigai kanker serviks saat inspeksi visual melalui inspekulo (sebelum dilakukan pemeriksaan IVA).

Variabel yang diteliti dalam penelitian ini adalah variabel terikat yakni kejadian lesi pra kanker serviks sedangkan variabel bebasnya adalah usia, usia pertama kai berhubungan seksual, jumlah pasangan seksual, jumlah paritas, paparan asap rokok, riwayat keluarga dengan kanker serviks, penggunaan pembersih vagina dan lama penggunaan kontrasepsi hormonal.

Analisis bivariat menggunakan uji statistik Chisquare untuk melihat kemaknaan hubungan antara variabel independen dan dependen. Hasil analisis dianggap bermakna bila didapatkan $p<0,05$. Analisis multivariat dilakukan dengan tujuan untuk melihat variabel independen yang paling dominan hubungannya dengan variabel dependen dengan 
menggunakan Multple Logistic Regression dengan metode Backward.

HASIL

\section{Analisis Univariat}

Tabel 1. Distribusi frekuensi variabel dependen dan independen

\begin{tabular}{|c|c|c|}
\hline Variabel & $f$ & $\%$ \\
\hline \multicolumn{3}{|c|}{ Kejadian lesi pra kanker serviks } \\
\hline \multicolumn{3}{|l|}{ Positif } \\
\hline \multirow[t]{2}{*}{ Negatif } & 17 & 4,7 \\
\hline & 345 & 95,3 \\
\hline \multicolumn{3}{|l|}{ Usia } \\
\hline$>35$ tahun & 177 & 48,9 \\
\hline$\leq 35$ tahun & 185 & 51,1 \\
\hline \multicolumn{3}{|c|}{$\begin{array}{l}\text { Usia pertama kali berhubungan } \\
\text { seksual }\end{array}$} \\
\hline$<20$ tahun & 192 & 53,0 \\
\hline$\geq 20$ tahun & 170 & 47,0 \\
\hline \multicolumn{3}{|c|}{ Jumlah pasangan seksual } \\
\hline Pasangan $>1$ & 19 & 5,2 \\
\hline Pasangan = 1 & 343 & 94,8 \\
\hline \multicolumn{3}{|l|}{ Jumlah paritas } \\
\hline$\geq 4$ kali & 43 & 11,9 \\
\hline$<4$ kali & 319 & 88,1 \\
\hline \multicolumn{3}{|l|}{ Paparan asap rokok } \\
\hline Terpapar & 310 & 85,6 \\
\hline Tidak terpapar & 52 & 14,4 \\
\hline \multicolumn{3}{|c|}{ Riwayat keluarga kanker serviks. } \\
\hline \multicolumn{3}{|l|}{ Ada } \\
\hline \multirow[t]{2}{*}{ Tidak ada } & 6 & 1,7 \\
\hline & 356 & 98,3 \\
\hline \multicolumn{3}{|c|}{ Penggunaan pembersih vagina } \\
\hline Menggunakan & 137 & 37,8 \\
\hline Tidak menggunakan & 225 & 62,2 \\
\hline \multicolumn{3}{|c|}{ Penggunaan alat kontrasepsi } \\
\hline Alamiah & 116 & 32,0 \\
\hline Non- Hormonal & 41 & 11,4 \\
\hline Hormonal & 205 & 56,6 \\
\hline $\begin{array}{l}\text { Lama penggunaan } \\
\text { hormonal }\end{array}$ & & \\
\hline$\geq 5$ tahun & 61 & 29,8 \\
\hline$<5$ tahun & 144 & 70,2 \\
\hline
\end{tabular}

Tabel 1 menunjukkan bahwa dari 362 responden didapatkan 4,7\% diantaranya positif lesi pra kanker serviks, 48,9\% berusia >35 tahun, 53,0\% melakukan hubungan seksual pertama kali pada usia <20 tahun, 5,2\% responden memiliki pasangan seksual $>1,11,9 \%$ responden dengan jumlah paritas $\geq 4$ kali. Terdapat 85,9\% responden terpapar dengan asap rokok, 1,7\% dengan riwayat keluarga yang menderita kanker serviks, 37,8\% menggunakan pembersih vagina dan $29,8 \%$ responden yang menggunakan kontrasepsi hormonal selama $\geq 5$ tahun.

\section{Analisis Bivariat}

Tabel 2. Hubungan beberapa faktor resiko kejadian lesi pra kanker serviks

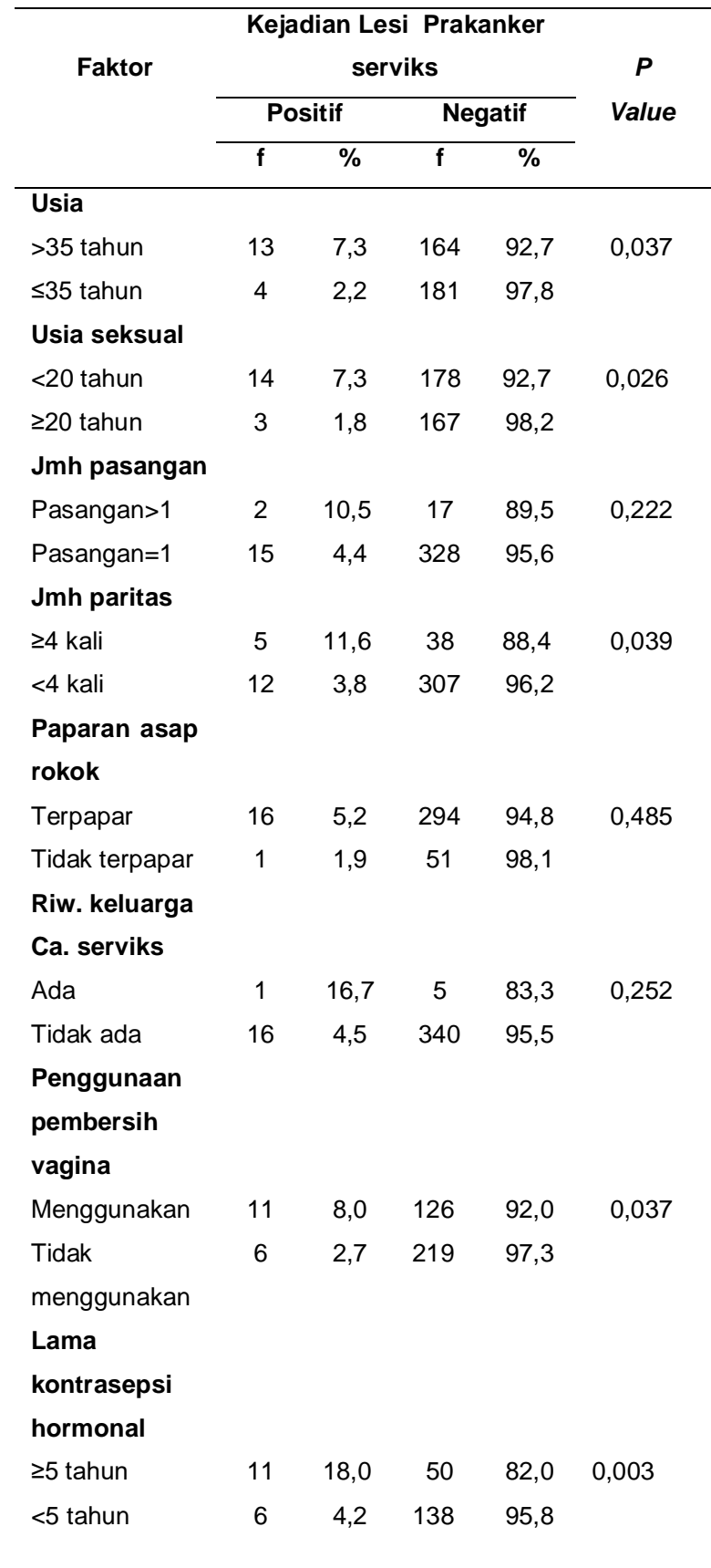

Analisis bivariat dilakukan untuk melihat hubungan antara variabel dependen dan independen dengan menggunakan uji statistik Chi-square. Pada 
Tabel 2 diketahui bahwa terdapat hubungan usia, usia pertama kali berhubungan seksual, jumlah paritas, penggunaan pembersih vagina dan lama penggunaan kontrasepsi hormonal dengan kejadian lesi pra kanker serviks dengan nilai $p<0,05$. Namun tidak terdapat hubungan jumlah pasangan seksual, paparan asap rokok dan riwayat keluarga dengan kanker serviks dengan kejadian lesi pra kanker serviks dengan nilai $p>0,05$.

\section{Analisis Multivariat}

Tabel 3. Model akhir analisis multivariat

\begin{tabular}{lccccc}
\hline Variabel & B & Wald & Sig & $\begin{array}{c}\text { Exp } \\
(\boldsymbol{B})\end{array}$ & Cl 95\% \\
\hline Usia & 1,424 & 4,469 & 0,035 & 4,152 & $\begin{array}{c}1,109- \\
15,540\end{array}$ \\
Usia & & & & & \\
pertama & & & & & \\
$\begin{array}{l}\text { berhub.s } \\
\text { eksual }\end{array}$ & 1,807 & 7.031 & 0,008 & 6,092 & $1,602-$ \\
$\begin{array}{l}\text { Lama } \\
\text { Ber-KB }\end{array}$ & 1,140 & 3,554 & 0,059 & 3,127 & $0,956-$ \\
hormonal & & & & & 10,230 \\
\hline
\end{tabular}

Berdasarkan Tabel 3 dapat disimpulkan bahwa dari seluruh variabel independen yang diteliti, variabel yang menjadi faktor paling dominan berhubungan dengan kejadian lesi pra kanker serviks adalah usia pertama kali berhubungan seksual dengan $P<0,05$. Nilai OR =6,092 yang artinya usia pertama kali berhubungan seksual $<20$ tahun memiliki peluang risiko 6,092 kali untuk mengalami kejadian lesi pra kanker serviks dibandingkan dengan usia $\geq 20$ tahun.

\section{PEMBAHASAN}

Pada penelitian ini didapatkan hasil yaitu terdapat hubungan yang signifikan pada usia, usia pertama kali berhubungan seksual, jumlah paritas, penggunaan pembersih vagina dan lama penggunaan kontrasepsi hormonal terhadap kejadian lesi pra kanker serviks dengan nilai Pvalue $<0,05$. Sedangkan jumlah pasangan seksual, paparan asap rokok dan riwayat keluarga dengan kanker serviks tidak memiliki hubungan yang bermakna dengan kejadian lesi pra kanker serviks dengan $p>0,05$.

\section{Hubungan Usia dengan Kejadian Lesi Pra Kanker Serviks}

Pada analisis bivariat menggunakan uji Chisquare, terdapat hubungan yang signifikan antara usia dengan kejadian lesi pra kanker serviks dengan $\mathrm{p}=$ $0,037(p<0,05)$. Hasil penelitian ini relevan dengan hasil penelitian yang dilakukan oleh Wahyuningsih (2014) di Puskesmas Jatinegara Jakarta bahwa sebagian besar kejadian IVA positif meningkat pada usia $>35$ tahun. ${ }^{17}$ Pada lokasi yang berbeda, Nindrea (2017) melakukan penelitian di RS Dr. Mohammad Hoesin Palembang juga didapatkan hasil bahwa lebih dari separuh (70\%) wanita yang berumur $>35$ tahun menderita lesi pra kanker pada serviksnya. ${ }^{7}$ Lain halnya di kota Denpasar tepatnya di empat Puskesmas yang melayani IVA. Dewi (2017) mengambil kesimpulan atas penelitian dari 120 responden yang ditelitinya, didapatkan bahwa lesi pra kanker serviks lebih banyak terjadi pada usia >35 tahun (40-49 tahun). ${ }^{8}$ Semua hasil penelitian diatas sejalan juga dengan penelitian bahwa puncak kejadian kanker leher rahim adalah pada usia 40-55 tahun. ${ }^{18}$

Risiko kanker serviks meningkat dua kali setelah usia 35 tahun sampai 60 tahun. Meningkatnya risiko kanker pada usia lanjut merupakan gabungan dari meningkatnya dan bertambah lamanya waktu pemaparan oleh karsinogen serta semakin lemahnya sistem imunitas tubuh. Belum lagi pada periode ini masalah kesehatan berganti dengan gangguan kehamilan, kelelahan akibat merawat anak dan tuntutan karir. Kegemukan, kanker, depresi dan penyakit serius tertentu mulai menggrogoti di usia ini. ${ }^{19}$

\section{Hubungan Usia pertama kali berhubungan seksual dengan Kejadian Lesi Pra Kanker Serviks}

Analisis bivariat menggunakan uji Chi-square, terdapat hubungan yang bermakna antara usia wanita saat pertama kali berhubungan seksual dengan kejadian lesi prakanker serviks dengan $p=0,026$ $(p<0,05)$. Hal ini serupa dengan yang dikemukan di tinjauan pustaka di mana dari hasil penelitian Dewi, (2017) dilaporkan bahwa hubungan seksual pertama pada usia $<20$ tahun sensitif terhadap kejadian lesi pra 
kanker leher rahim. ${ }^{8}$ Menurut penelitian Anggraeni et al (2012) yang melakukan studi epidemiologi juga melaporkan kejadian kanker serviks meningkat $>10$ kali bila melakukan hubungan seksual pada usia 15-19 tahun. ${ }^{19}$

Penelitian lain yang dilakukan di Afrika bagian timur tepatnya di Rwanda oleh Makuza et al (2015) juga melaporkan hal yang serupa. Kejadian lesi pra kanker serviks meningkat pada wanita dengan usia melakukan hubungan seksual $<20$ tahun $(\mathrm{OR}=1,75$; $\mathrm{Cl}$ 95\%: 1,01-3,02) karena kondisi tersebut meningkatkan paparan oleh HPV resiko tinggi. ${ }^{10}$

Faktor risiko ini dihubungkan dengan karsinogen pada zona transformasi yang sedang berkembang dan paling berbahaya apabila terpajan HPV dalam 5-10 tahun setelah menarche. ${ }^{20}$ Hubungan seks idealnya dilakukan setelah seorang wanita benarbenar matang yang juga bergantung pada sel-sel mukosa yang terdapat di selaput kulit bagian dalam rongga tubuh. Umumnya sel-sel mukosa baru matang setelah wanita berusia 20 tahun ke atas. ${ }^{2}$ Kelainan sel yang mengarah kepada kanker serviks tidak terjadi dalam hitungan hari atau pun dalam hitungan bulan. Namun membutuhkan proses yang memakan waktu 10 hingga 20 tahun lamanya. Sehingga berhubungan seksual pertama kali usia <20 tahun merupakan jembatan menuju terjadinya lesi pra kanker serviks bahkan kanker serviks, karena dapat menjadi pemicu HPV menginfeksi lebih dalam oleh karena ketidaksiapan atau belum matangnya mukosa serviks pada usia tersebut dibandingkan berhubungan seksual di usia $\geq 20$ tahun. $^{21}$

\section{Hubungan Jumlah Pasangan dengan Kejadian Lesi Pra Kanker Serviks}

Analisis bivariat menggunakan uji Chi-Square, tidak terdapat hubungan yang bermakna antara jumlah pasangan seksual dengan kejadian lesi prakanker serviks dengan $p=0,222$ ( $p>0,05)$. Hasil pada penelitian ini juga tidak sesuai dengan penelitian dari Nindrea (2017) bahwa terdapat hubungan antara perilaku seksual yang dilihat dari jumlah pasangan seksualnya $(p=0,001<0,05)$. Dimana wanita yang memiliki pasangan seksual $>1$ memiliki peluang 13,3 kali berisiko mengalami lesi pra kanker serviks dibanding wanita yang memiliki pasangan $=1$
(CI95\%:2,81-63,11). ${ }^{7}$ Begitu juga dengan penelitian Handayani (2015) yang memaparkan bahwa responden yang mempunyai pasangan lebih dari 1 orang, mempunyai hasil tes IVA positif di bandingkan responden yang mempunyai 1 pasangan seksual. ${ }^{22}$

Ketidaksesuaian hasil pada penelitian ini dengan dua hasil penelitian diatas, kemungkinan terjadi karena pada penelitian ini hanya melihat dari jumlah pernikahan responden yang disahkan oleh hukum agama atau negara. Artinya masih terdapat kemungkinan tidak tergalinya informasi perilaku seksual responden saat sebelum atau setelah pernikahan. Sejalan dengan hal yang dikemukakan di atas bahwa perilaku seksual tidak hanya dilihat dari banyaknya jumlah pasangan seksual yang dimiliki wanita, namun juga banyaknya jumlah pasangan seksual yang dimiliki oleh pasangan wanita tersebut. ${ }^{3}$ Peningkatan kejadian tumor lebih sering terjadi pada wanita monogami yang suaminya sering berhubungan seksual dengan banyak wanita lain menimbulkan konsep "pria berisiko tinggi" sebagai vektor dari agen yang dapat menimbulkann infeksi. Wanita atau pasangan pria yang memiliki riwayat berganti pasangan seksual memungkinkan tertularnya penyakit kelamin salah satunya HPV. Virus ini akan mengubah sel-sel dipermukaan mukosa hingga membelah menjadi lebih banyak sehingga tidak terkendali dan menjadi kanker. ${ }^{23}$

\section{Hubungan Jumlah Paritas dengan Kejadian Lesi Pra Kanker Serviks}

Analisis bivariat menggunakan uji Chi-square, terdapat hubungan yang bermakna antara jumlah paritas dengan kejadian lesi prakanker serviks $p$ value $=0,039(p<0,05)$. Hasil penelitian ini relevan dengan hasil penelitian yang di lakukan oleh Makuza et al (2015) di negara Afrika bagian timur yakni wanita dengan paritas 4 atau lebih mempunyai risiko mengalami IVA positif 2,5 kali lebih besar dibanding paritas tiga atau kurang. ${ }^{10}$ Terdapat juga kesesuaian dengan hasil penelitian Damayanti et al (2015) bahwa terdapat hubungan antara paritas $>3$ dengan lesi pra kanker serviks dengan nilai $p=0,030 \quad(p<0,05) .{ }^{24}$ Menurut peneliti jumlah paritas yang tinggi dapat menjadi media perkembangan HPV masuk dan menginvasi permukaan seviks lebih dalam, salah 
satunya melalui perlukaan atau trauma yang disebabkan oleh persalinan pervaginam terlalu sering.

Wanita dengan paritas tinggi, selama kehamilan terjadi eversi epitel kolumner serviks yang menyebabkan dinamika baru epitel metaplastik imatur yang meningkatkan risiko transformasi sel terutama pada serviks sehingga terjadi infeksi HPV persisten. ${ }^{7}$ Efek hormonal yang diinduksi kehamilan pada serviks dapat mempengaruhi genom HPV yang responsif terhadap progesteron. Progesteron dapat menginduksi onkogen HPV menjadi stabil sehingga terjadi integrasi DNA virus ke dalam genom sel penjamu dan menurunkan kekebalan mukosa zona transformasi. ${ }^{20}$ Kemudian saat hamil, zona transformasi dari ektoserviks melebar ditambah lagi dengan trauma/luka akibat proses persalinan normal yang berkali-kali sehingga paparan oleh HPV akan lebih mudah. ${ }^{21}$

\section{Hubungan Paparan Asap Rokok dengan Kejadian Lesi Pra Kanker Serviks}

Pada analisis bivariat menggunakan uji Chisquare, tidak terdapat hubungan yang bermakna antara paparan asap rokok dengan kejadian lesi pra kanker serviks dengan nilai $p$ value $>0,05(p=0,485)$. Penelitian ini tidak sesuai dengan hasil penelitian yang di lakukan oleh Dewi et al (2013) di wilayah kerja dari dua puskesmas terpilih di Bali, bahwa terdapat hubungan antara paparan asap rokok dengan kejadian lesi pra kanker serviks $(p=0,0001 ; O R=4,75 ; \mathrm{Cl}$ 95\%:2,19-10,33). ${ }^{25} \mathrm{Hal}$ ini disebabkan karena perokok $(\mathrm{OR}=2,5)$ dan menghirup asap rokok $(\mathrm{OR}=1,4)$ memiliki resiko yang sama untuk menderita kanker serviks. ${ }^{6}$ Penelitian lain oleh Nindrea (2017) di Palembang pada semua wanita Pekerja Seks Komersial yang berobat ke RS. Dr. Mohammad Hoesin Palembang, juga terdapat hubungan antara paparan asap rokok dengan kejadian lesi pra kanker serviks ( $p=0,032 ; \quad$ OR=6,33; Cl 95\%:1,37-29,21). ${ }^{7}$ Sedang kan penelitian yang dilakukan oleh Chairani (2018) diperoleh hasil yang justru sesuai dengan hasil pada penelitian ini, bahwa tidak terdapat hubungan antara paparan asap rokok dengan kejadian lesi pra kanker serviks $(p=0,346 ; O R=1,6 ; C l$ 95\%: 0,496$2,655) \cdot{ }^{26}$
Penelitian tentang dua variabel ini menunjukkan hasil yang kontroversial. Hal ini disebabkan karena adanya perbedaan karakteristik populasi dan jumlah sampel dalam penelitian. Selain itu menurut peneliti, keterbatasan dalam penelitian ini adalah pada kuisioner hanya menanyakan merokok apa tidak pada responden dan suami atau keluarga yang tinggal satu rumah merokok atau tidak. Tidak menanyakan frekuensi atau lama terpapar asap rokok serta jumlah batang rokok yang di konsumsi.

Beberapa mekanisme molekuler telah diyakini bahwa merokok dapat berkontribusi pada karsinogenesis pada serviks yang melibatkan langsung paparan terhadap DNA dalam sel-sel epitel serviks. ${ }^{11}$ Asap rokok dari satu batang rokok mengandung tar, nikotin, karbondioksida, benzo [a] pyrene (BAP) dan bahan kimia berbahaya lainnya dengan jumlah mencapai ribuan dan efek langsung bahan-bahan tersebut pada serviks adalah menurunkan status imun lokal dan meningkatkan kemungkinan integrasi DNA virus ke dalam genom inang. Efek jangka panjang nya adalah proliferasi seluler terganggu, menghambat apoptosis \& stimulasi faktor pertumbuhan endotel vaskuler dengan peningkatan kepadatan pembuluh darah mikro. Sehingga dapat menjadi ko-karsinogen infeksi virus HPV yang akhirnya merusak epitel serviks dan menyebabkan neoplasma atau populasi sel kanker serviks. $^{27}$

\section{Hubungan Riwayat Keluarga dengan Kanker Serviks dengan Kejadian Lesi Pra Kanker Serviks}

Analisis bivariat menggunakan uji Chi-square, tidak terdapat hubungan antara riwayat keluarga yang menderita kanker serviks dengan kejadian lesi pra kanker serviks dengan nilai $p$ value $>0,05(p=0,252)$. Hasil penelitian ini tidak sesuai dengan hasil penelitian yang dilaporkan oleh Sarwono (2017) bahwa terdapat hubungan yang bermakna antara wanita usia subur yang memiliki keluarga dengan riwayat kanker serviks dengan kejadian lesi pra kanker serviks ( $p=0,031$; OR=1,831; $\quad C \mid 95 \%=1,057-3,173$ ) artinya riwayat keluarga dengan kanker servik memiliki peluang 1,831 
kali beresiko terkena kanker serviks. ${ }^{11}$ Hasil penelitian ini juga tidak sejalan dengan hasil penelitian Chairani (2018) yang menyimpulkan bahwa terdapat pengaruh riwayat keluarga dengan kejadian kanker serviks $(p=0,002 ; O R=3,382 ; \quad C l \quad 95 \%=1,573-7,272)$ dimana artinya adalah responden yang memiliki riwayat keluarga menderita kanker serviks berpeluang 3,382 kali lebih besar menderita kanker serviks dibandingkan dengan yang tidak memiliki riwayat keluarga yang menderita kanker serviks. ${ }^{26}$

Ketidaksesuaian hasil yang ada pada penelitian ini dengan teori yang ada berarti ada faktor risiko lainnya yang dapat memicu kejadian lesi pra kanker serviks seperti usia, sistem imunitas tubuh, usia pertama kali berhubungan seksual. Beberapa peneliti mengungkapkan bahwa sistem kekebalan tubuh yang lemah juga sangat berperan penting dalam memicu transformasi sel skuamosa hingga menghasilkan selsel Cervix Intraephitelia Neoplasia. Kemungkinan adanya perbedaan karakteristik populasi dan sampel pada masing-masing tempat penelitian. Riwayat keluarga merupakan salah satu faktor yang penting dari banyak faktor lainnya, mengingat kanker serviks bisa dipengaruhi oleh kelainan genetika. Beberapa keluarga bisa jadi memiliki risiko lebih tinggi menderita kanker tertentu dibandingkan dengan keluarga lainnya.

\section{Hubungan Penggunaan Pembersih Vagina dengan Kejadian Lesi Pra Kanker Serviks}

Pada analisis bivariat menggunakan uji Chisquare, terdapat hubungan antara penggunaan pembersih vagina dengan kejadian lesi pra kanker serviks dengan nilai $p<0,05 \quad(p=0,037)$. Hasil penelitian ini sejalan dengan hasil penelitian yang dilakukan oleh Chairani (2018) bahwa terdapat hubungan yang bermakna antara pemakaian pembersih vagina terhadap kejadian kanker seviks $(p=0,001 ; O R=7 ; C l$ 95\%=3,078-15,845) yang arti nya penggunaan pembersih vagina memiliki peluang risiko 7 kali lebih besar menderita kanker serviks dibanding yang tidak menggunakan pembersih vagina. ${ }^{26} \mathrm{Hal}$ ini disebabkan karena dapat mengubah lingkungan kimia vagina dan serviks rentan dengan perubahan patologis dan kanker serviks. ${ }^{27}$
Menurut peneliti penggunaan pembersih vagina baik yang komersil maupun yang tradisional tanpa indikasi, dapat mengganggu lingkungan vagina sehingga mengundang masuknya bakteri jahat yang menyebabkan gatal, ritasi atau infeksi pada vagina atau serviks. Infeksi yang terjadi tentunya akan menimbulkan peradangan sehingga terjadi mikro lesi pada epitel serviks yang pada akhirnya dapat menjadi media HPV meninvasi lebih dalam.

Organ kewanitaan memiliki kemampuan yang tidak banyak para wanita mengetahuinya yakni mampu melakukan pertahanan yang cukup baik dengan hidupnya bakteri baik di daerah organ tersebut. Lactobacillus acidophilus sebagai bakteri baik, bertugas untuk menjaga kesimbangan ekosistem vagina dengan menjaga keasaman dari vagina yang sehat, menghasilkan bakteriosin dan hidrogen peroksida. Ekosistem daerah vagina juga dipengaruhi oleh hormon estrogen. ${ }^{26}$ Hormon estrogen berfungsi untuk menentukan kadar zat gula sebagai simpanan energi dalam tubuh berupa glikogen, dimana glikogen merupakan makanan bagi bakteri laktobasilus yang akan dimetabolisme. Sisa metabolisme tersebut berupa asam laktat yang dapat mempengaruhi tingkat keasaman $\mathrm{pH}$ (potensial Hidrogen) vagina 3,8-4,5. ${ }^{21}$

Penggunaan obat-obatan pembersih vagina seperti deodoran ataupun antisepsik baik yang komersil maupun yang tradisional secara terus menerus atau terlalu sering akan menyebabkan iritasi pada vagina bahkan serviks yang memicu perubahan sel yang mengarah pada kanker. Kondisi ini di perburuk oleh kebiasaan dalam teknik mencuci vagina yang seharusnya dilakukan satu arah dari depan kebelakang, namun dilakukan sebaliknya. ${ }^{27}$

\section{Hubungan Lama penggunaan Kontrasepsi Hormonal dengan Kejadian Lesi Pra Kanker Serviks}

Berdasarkan uji statistik pada Tabel 1 diperoleh analisis univariat yakni dari 362 responden didapat $56,6 \%$ responden yang menggunakan alat kontrasepsi hormonal, $11,4 \%$ non-hormonal dan $32,0 \%$ responden menggunakan metode KB alamiah. 
Distribusi jenis alat kontrasepsi dengan metode hormonal yang digunakan oleh responden yakni pil kombinasi (54,6\%), suntik (34,2\%) dan implan $(11,2 \%)$. Sedangkan berdasarkan lamanya penggunaan alat kontrasepsi hormonal tersebut, didapatkan responden dengan lama menggunakan kontrasepsi hormonal $\geq 5$ tahun sebanyak $29,8 \%$ dan $<5$ tahun sebesar $70,2 \%$.

Analisis bivariat menggunakan uji Chi-square, terdapat hubungan antara lama penggunaan kontrsepsi hormonal dengan kejadian lesi pra kanker serviks. Hal ini dibuktikan dengan perolehan nila $p$ value $=0,003$. Hasil pada penelitian ini sesuai dengan hasil penelitian Parwati et al (2015) di dua puskesmas yang ada di Denpasar-Bali bahwa terdapat hubungan antara variabel lama penggunaan kontrasepsi hormonal dengan kejadian lesi pra kanker serviks $\left(p=0,045 ;\right.$ OR=10,7; Cl 95\%: 1,04-108,17). ${ }^{28}$ Menurut WHO kontrasepsi oral yang dipakai dalam jangka panjang lebih dari 5 tahun dapat meningkatkan risiko 1,53 kali mengalami kanker serviks. ${ }^{3}$

Penggunaan kontrasepsi hormonal dengan komposisi estrogen dan progestin yang bekerja melalui reseptornya di sel target, dapat meningkatkan insiden ektropion serviks dan potensi karsinogen lainnya. Estrogen dan progestin juga dapat mempengaruhi sel-sel serviks secara langsung, mempromosikan integrasi DNA HPV ke dalam genom inang, merangsang transkripsi DNA HPV dan meningkatkan proliferasi sel. Steroid sexs hormone dapat meningkatkan ekspresi HPV-16 E6 dan gen E7 dengan inaktivasi dan atau degradasi p53 dan protein $\mathrm{Rb}$ yang kemudian menyebabkan kegagalan mekanisme apoptosis dan peningkatan karsinogenesis pada sel serviks. Terlebih jaringan pada serviks merupakan salah satu sasaran yang disukai oleh hormon steroid wanita. ${ }^{29}$

\section{Faktor paling dominan yang berhubungan dengan kejadian lesi pra kanker serviks}

Analisis multivariat telah dilakukan dengan menggunakan uji Multiple Logistic Regression pada variabel yang ada. Faktor risiko yang paling dominan terhadap kejadian lesi pra kanker serviks di wilayah kerja Puskesmas Muara Bungo 1 adalah usia pertama kali berhubungan seksual dengan nilai Odd Ratio=
6,092 yang memilliki arti bahwa seorang wanita subur dengan usia pertama kali berhubungan seksual $<20$ tahun memiliki peluang 6,092 kali berisiko untuk mengalami kejadian lesi pra kanker serviks dibanding usia $\geq 20$ tahun. Hasil penelitian ini relevan dengan penelitian Makuza et al (2015) di Rwanda Afrika bagian timur diperoleh hasil tentang kejadian lesi pra kanker serviks meningkat pada wanita dengan usia melakukan hubungan seksual $<20$ tahun $(O R=1,75) .{ }^{10}$

Lesi pra kanker servik pada wanita dengan usia pertama kali berhubungan seksual <20 tahun ini tentunya berhubungan dengan belum matangnya organ reproduksi seorang wanita pada usia $<20$ tahun secara biologis. Infeksi pertama serviks oleh HPV sering terjadi setelah terjadinya hubungan seksual pertama karena usia $<20$ tahun serviks rentan terhadap rangsangan dari luar berupa bahan-bahan karsinogen seperti virus HPV atau zat-zat kimia yang dibawa oleh sperma. ${ }^{25}$ Proses terjadinya lesi pra kanker pada usia pertama kali berhubungan seksual $<20$ tahun ini erat kaitannya dengan proses metaplasia pada lapisan endoserviks menjadi epitel skuamosa pada daerah transformasi. Ketika virus HPV masuk, maka virus tersebut akan langsung melekat pada sel yang berada pada pada lapisan basal epitel serviks kemudian DNA virus akan berintegrasi dengan DNA penjamu sehingga sel skuamosa yang mengalami metaplasia pada zona transformasi akan mengalami displasia menjadi lesi pra kanker serviks. Kemudian sel ini akan terus membelah tanpa terkendali dan menjadi kanker serviks. ${ }^{20}$

\section{SIMPULAN}

Lesi pra kanker serviks akan meningkat kejadiannya pada wanita PUS di wilayah kerja Puskesmas Muara Bungo 1, yang berusia >35 tahun, usia pertama kali berhubungan seksual <20 tahun, jumlah paritas $\geq 4$ kali dan menggunakan pembersih vagina serta lama penggunaan kontrasepsi hormonal $\geq 5$ tahun

Faktor risiko yang paling dominan pada wanita PUS yang berada di wilayah kerja Puskesmas Muara Bungo 1, yang menyebabkan kejadian lesi pra kanker serviks adalah usia pertama kali berhubungan seksual $<20$ tahun 


\section{SARAN}

Dinas kesehatan Kabupaten Bungo melalui Puskesmas Muara Bungo 1 meningkatkan koordinasi dengan banyak lintas sektoral salah satunya dengan Kantor Urusan Agama berupa upaya promotif yakni edukas i terkait pernikahan diusia yang tepat $(\geq 20$ tahun) serta upaya preventif berupa kebijakan pemberian imunisasi HPV pada wanita <20 tahun yangn ingin menikah. Selain itu disarankan adanya edukasi pada kelompok wanita PUS yang berisiko terhadap kejadian lesi pra kanker serviks serta membangun kesadaran masyarakat terhadap pentingnya pemeriksaan deteksi dni kanker serviks dengan metode VIA

\section{UCAPAN TERIMA KASIH}

Terima kasih dan penghargaan peneliti sampaikan kepada semua pihak yang telah membantu dalam penelitian ini, serta kepada kepala Dinas Kesehatan Kabupaten Bungo dan Kepala Puskesmas Muara Bungo 1.

\section{DAFTAR PUSTAKA}

1. Aziz MF, Andrijono, Saifuddin AB. Buku acuan nasional onkologi \& ginekologi. Jakarta: Yayasan Bina Pustaka Sarwono Prawirohardjo; 2010. hlm. $112-274$

2. Andrijono. Kanker serviks. Edisi ke-2. Jakarta: Divisi Onkologi Departemen Obstetri -Gynekologi FKUI; 2009.hlm.1-9.

3. World Health Organization (WHO). Estimated cervical cancer incidence worldwide in 2013 \& human papillovirus and related Cancer in Indonesia (diakses t25 Agustus 2018). Tersedia dari: http://www.ncc.online.ora/world

4. International Agency for Research on Cancer (IARC). Globocan 2018: Incidence, mortality, 5 years-Prevalence and new cases disabilityadjusted life years (DALYs) cancer of the world. IARC Cancer Base (diakses 26 Desember 2018). Tersedia dari: http://globocan.iarc.fr/Default.aspx

5. Female Cancer Program Foundation (FCPF). Target dan sasaran MPS see and treat regional Bali. Denpasar 2010 (diunduh Agustus 2018). Tersedia dari: http://www.femalecancerfoundation. org/en/projects/female-cancer-program-indonesia/
6. Kementerian Kesehatan Republik Indonesia (Kemenkes RI). Pusat Data \& Informasi Kementerian Kesehatan RI 2015: Stop Kanker (diunduh Oktober 2018). Tersedia dari: http://www.depkes.go.id/resources/download/pusd atin-stopkanker/profil.pdf

7. Nindrea RD. Prevalensi dan faktor yang mempengaruhi lesi pra kanker serviks pada wanita. J Endur. 2017;2(1):53.

8. Dewi IGAAN. Pendekatan faktor-faktor dalam mendeteksi lesi prakanker leher rahim di kota Denpasar. J Infokes Apikes Citra Med Surakarta. 2017;7(2):56-62.

9. Aziz MF, Cornain S, Wibowo N, Andrijono, Budiningsih S, Nuranna L, et al. Buku acuan program pencegahan kanker serviks "see and treat”. Jakarta: YKI; 2013.hlm. 82-104.

10. Makuza JD, Nsanzimana S, Muhimpundu MA, Pace LE, Ntaganira J, Riedel DJ. Prevalence and risk factors for cervical cancer and pre-cancerous lesions in Rwanda. Pan Afr Med J. 2015;22:1-8.

11. Sarwono B. Lesi serviks pada wanita usia subur dalam pemeriksaan inspeksi visual asam asetat. Jurnal Kebidanan, 2017;6(12):27-37.

12. Kementerian Kesehatan Republik Indonesia (Kemenkes RI). Pusat data \& informasi profil kesehatan tahun 2018 (diakses 10 Oktober 2019). Tersedia dari: http://www.depkes.go.id/resources/ download/pusdatin/infodatin/infodatin-kanker.pdf

13. Juanda D, Kesuma H. Pemeriksaan metode IVA (inspeksi visual asam asetat) untuk pencegahan kanker serviks. J Kedokteran dan Kesehatan. 2015;2(2):169-74.

14. Dinas Kesehatan (Dinkes) Provinsi Jambi. Laporan bulanan inspeksi visual asam asetat (IVA) provinsi Jambi tahun 2018. Jambi: P2PTM \& Keswa Dinkes Provinsi Jambi.

15. Dinas Kesehatan (Dinkes) Kabupaten Bungo. Profil kesehatan kabupaten Bungo tahun 2017. Kabupaten Bungo: Dinkes Kabupaten Bungo. 2018.

16. Rumah Sakit Umum Daerah (RSUD) H. Hanafie. Register patologi anatomi: register hasil pemeriksaan patologi anatomi pasien bulan Januari-November 2018. Muara Bungo: RSUD H. Hanafie; 2018. 
17. Wahyuningsih T, Mulyani EY. Faktor risiko terjadinya lesi prakanker serviks melalui deteksi dini dengan metode Iva (Inspeksi Visual Dengan Asam Asetat). Forum IIm. 2014;11:192-209.

18. Kementerian Kesehatan RI. Riset kesehatan dasar (Riskesdas). Jakarta: Badan Penelitian dan Pengembangan Kesehatan Kementerian RI tahun 2013 (diakses 18 Agustus 2018). Tersedia dari: http://www.depkes.go.id/resources/dowload/genera l/Hasil\%20Riskesdas\%202013.pdf.

19. Anggraeni TD, Laila N, Catherine, Cecep SS, Fitri $\mathrm{R}$, Christine $\mathrm{WH}$, et al. Distribution of age, stage and histopathology of cervical cancer: a retrospective study on patients at Dr. Cipto Mangunkusumo Hospital Jakarta, Indonesia 20062010. Indonesian Journal Obstetri Gynecology. 2012;35(1): 21-4.

20. Adekunle OO. Cervical intraepithelial neoplasia (CIN) (squamous dysplasia). Intraepithelial Neoplasia. 2012; 279-310. Tersedia dari: http://cdn.intechopen.com/pdfs/27770/InTechCervi cal intraepithelial neoplasia cin squamous dyspl asia .pdf

21. Rasjidi I. Manual pra kanker serviks. Jakarta: Sagung Seto; 2014.hlm. 5-13, 37-43.

22. Handayani IF. Perbandingan karakteristik dan pengetahuan tentang kanker serviks pada wanita dengan inspeksi visual asam asetat (IVA) Positif di Pesisir dan Perkotaan. J Kebidanan, 2015; VII(01):1-11.

23. Sjamsuddin S. Pencegahan dan deteksi dini kanker seviks. Jakarta: Cermin Dunia Kedokteran; 2001. hlm.8-13.
24. Darmayanti, Harpisah, Kirana R. Faktor-faktor yang berhubungan dengan kanker leher rahim di RSUD Ulin Banjarmasin 1,2,3. J Kesehatan. 2015; Vl:172-7.

25. Dewi IGAAN, Sawitri AAS, Adiputra N. Laporan hasil penelitian paparan asap rokok dan higiene diri merupakan faktor risiko lesi prakanker leher rahim di kota Denpasar tahun 2012. Cigarette smoke exposure and personal hygiene as determinants for cervical pre- cancer lession in Denpasar 2012. P. Public Heal Prev Med Arch. 2013;1(1):84-91.

26. Chairani R. Faktor risiko yang mempengaruhi kejadian kanker serviks pada wanita di Rumah Sakit Umum daerah dr. Pirngadi kota Medan (tesis). Medan: Fakultas Kesehatan Masyarakat Universitas Sumatera Utara; 2018.

27. Desen W. Onkologi klinis. Guangzhou China: University of Medical Sciences Cancer Center; 2009. hlm.177-289.

28. Parwati NM, Artawan IWG, Putra E, Karmaya M. Kontrasepsi hormonal dan riwayat infeksi menular seksual sebagai faktor risiko lesi pra-kanker leher rahim. Public Heal Prev Med Arch. 2015;3(2):1738.

29. Gaduci A, Barsoti C, Coiso S, Domenici L, Genazzani A. Cervical cancer: smoking habit, immune suppresion, oral contraceptive use and hormone replacement therapy use and cervical carcinogenesis: a review of literature. Gynecological Endocrinology. 2011;7(8):597-604. 